СПОСОБ МИНИМИЗАЦИИ МЕХАНИЧЕСКИХ НАПРЯЖЕНИЙ В ЧУВСТВИТЕЛЬНОМ ЭАЕМЕНТЕ МИКРОМЕХАНИЧЕСКИХ УСТРОЙСТВ ПІРИ МОНТАЖЕ В КОРПІУС

\title{
A METHOD OF MINIMIZING MECHANICAL STRESSES IN A SENSITIVE ELEMENT OF MICROMECHANICAL DEVICES AT PACKAGING
}

УДК 621.3.084.2/621.3.032.5

\author{
ВОЛКОВА ЕКАТЕРИНА ИВАНОВНА \\ Инженер-исследователь \\ kattykat@inbox.ru
}

МАНИН ПАВЕЛ АЛЕКСАНДРОВИЧ

Начальник отдела исследования и разработки аналоговых

и цифро-аналоговых интегральных схем

maninpavel@yandex.ru

\section{ПОПКОВ СЕРГЕЙ АЛЕКСЕЕВИЧ}

К.ф.-м.н., стариий научный сотрудник

popkov-fzf@yandex.ru

Федеральное государственное унитарное предприятие федеральный научно-производственный центр «Научноисследовательский институт измерительных систем им. Ю.Е. Седакова»

603137, Нижний Новгород, ул. Тропинина, 47

\author{
VOLKOVA CATHERINE I. \\ Research engineer \\ kattykat@inbox.ru \\ MANIN PAVEL A. \\ Head of research and development of analog \\ and digital-analog integrated circuits \\ maninpavel@yandex.ru
}

POPKOV SERGEY A.

Ph.D, senior research assistant

popkov-fzf@yandex.ru

\author{
FSUE "FRPC Research Institute \\ of Measuring Systems named after Yu. Ye. Sedakov" \\ 47 Tropinina St., Nizhny Novgorod, 603137
}

В работе рассматриваются результаты исследований механических напряжений, возникающих в чувствительном элементе (ЧЭ) при его монтаже в корпус. Осуществляется поиск конструкции опорного кристалла, который при температурных изменениях позволяет минимизировать механические напряжения, обеспечивая механическую развязку между самим ЧЭ и корпусом прибора.

Ключевые слова: иувствительный элемент; микроэлектромеханические системы (МЭМС); микросистемная техника (МСТ); опорный кристалл; микродатчик давления.

The study highlights the results of mechanical stresses occurred in a sensitive element (SE) under package, as well as mechanical stresses effect on output characteristics based on an exemplary pressure microsensor (PMS). The paper gives data on digital simulation of SE chip strain caused by thermal expansion - compression at packaging SE chip in the support chip-package system. A search has been performed for a support chip structure which makes it possible to reduce mechanical stresses under temperature variations and to assure mechanical decoupling between SE itself and the device package.

Keywords: sensitive element; microelectromechanical systems (MEMS); microsystem technology (MST); support chip; microaccelerometer; pressure microsensor.

\section{BВEАЕНИЕ}

На протяжении многих лет особое внимание уделяется операции по корпусированию ЧЭ микроэлектромеханических систем (МЭМС) ввиду важной роли, которую она играет в конечных параметрах готового прибора [1]. Среди многих предложенных концепций по развязке первичного преобразователя или ЧЭ наиболее устойчивые решения получило направление, согласно которому упаковка ЧЭ может быть выполнена гораздо эффективнее, если требуемые параметры по механической развязке уже заложены в кремниевом промежуточном слое или опорном кристалле. Одной из таких функций опорного кристалла является минимизация механических напряжений, возникающих, например, как следствие термического линейного расширения основания корпуса прибора, на котором установлен ЧЭ.
На сегодняшний день существуют несколько фундаментальных направлений в области микросистемной техники (МСТ), наиболее чувствительных к проблемам корпусирования. Одно из таких направлений включает в себя интегральные преобразователи давления, принцип работы которых в ряде случаев базируется на тензорезистивном эффекте. Использование данного эффекта как основного принципа работы преобразователя получило широкое распространение благодаря относительно высокой точности измеряемых характеристик ЧЭ [2] и простоте конструкции, в которой используются тензорезисторы. Однако ряд факторов могут ухудшать выходные характеристики. Наиболее остро обстоят дела с механическими напряжениями, которые привносят свой вклад в зависимость выходного сигнала от прикладываемого внешнего давления среды. Вклад от механических 
напряжений может приводить к смещению и дрейфу нуля зависимости, появлению гистерезиса в рабочем цикле, изменению времени отклика при резком изменении температуры. Таким образом, для разработки МДД, обладающего высокой точностью, требуется, чтобы все составляющие элементы проектируемого ЧЭ МДД были согласованы между собой с минимальным количеством механических напряжений на переходных интерфейсах в системе мембрана ЧЭ - корпус прибора, или действие отрицательных факторов можно было бы компенсировать.

В данной работе рассматривается задача по поиску оптимальной конструкции опорного кристалла. Проводится сравнительный анализ среди приведенных вариантов по развязке с корпусом прибора и предлагается вариант конструкции опорного кристалла, который позволяет сократить передачу паразитных воздействий на ЧЭ МДД и, тем самым, уменьшить нежелательные составляющие в выходной характеристике.

\section{ТЕОРЕТИЧЕСКАЯ ЧАСТЬ}

Несомненно, что в борьбе за максимально достижимый результат проявляются как положительные, так и отрицательные стороны в разработке конечного продукта. Если принять за основной параметр точность ЧЭ, то вторым по важности критерием является простота в технологии его изготовления. Поэтому дальнейшее рассмотрение и выбор опорных кристаллов как части ЧЭ среди наиболее распространенных видов велись на основе этих двух критериев. Конструкция поддерживающего кристалла должна обеспечивать минимальный вклад от нежелательных составляющих в выходной сигнал, и сам опорный кристалл можно изготовить в едином цикле на базе технологической линии микроэлектронных устройств.
Наибольшую популярность среди сравнительно недорогих ЧЭ МДД получила механическая развязка с корпусом в виде массивного опорного кристалла, высота которого в несколько раз превышает толщину кристалла ЧЭ, (модель I, показана на рис. 1a) [3], или такого же основания, но уже закрепленного на керамической трубочке (модель II, показана на рис. 1б). Установка мембраны ЧЭ подобным образом в первом приближении позволяет частично снять механические напряжения, связанные с корпусированием ЧЭ.

Монтаж мембраны ЧЭ на опорный кристалл (модель I и II) осуществляется путем склеивания, пайки и легирования [1]. Наряду с различными способами наиболее часто опорный кристалл типа модели I получают при помощи электростимулированного (анодного) соединения нескольких пластин кремния или боросиликатных стекол, которые, в свою очередь, объединяют с кристаллом ЧЭ [4]. Однако механическая развязка такого вида в технологическом ключе не всегда является эффективной и оправданной из-за возрастающего количества операций и используемого оборудования по сравнению с циклом обработки стандартной кремниевой пластины. К тому же, существенным недостатком этой концепции является требование, что все входящие в ЧЭ и опорный кристалл слои должны иметь согласование между тепловыми коэффициентами расширения (ТКР) материала. При этом операция анодного соединения двух кристаллов приводит к преднапряженному состоянию в мембране ЧЭ, что негативно сказывается на характеристиках тензорезисторов и приводит к начальной разбалансировке моста в электрической схеме, в которую включается ЧЭ. Указанное обстоятельство будет продемонстрировано ниже на примере зависимости выходного сигнала ЧЭ МДД от приложенного внешнего давления (рис. 8).

Альтернативным подходом к разработке формы опорного кристалла стало использование в его конструкции заранее

\section{INTRODUCTION}

Over many years a particular attention has been paid to microelectromechanical systems (MEMS) SE packaging due to its significance for final parameters of the finished device [1]. Among lots of proposed concepts for decoupling a primary transducer or SE, the worthiest solutions have appeared due to the following trend: SE package is much more efficient if the required parameters of mechanical decoupling are set beforehand in a silicon intermediate layer or support chip. One of the support chip functions is to minimize mechanical stresses that happen, for example, as a result of thermal linear expansion of a device package base with installed SE.

At present there are several fundamental trends in microsystem technology (MST) that are most package- sensitive. One of these covers integrated pressure transducers whose operation principle is based in some cases on the piezoresistive effect. The application of this effect as the key operation principle has been widely spread due to relatively high accuracy of SE [2] measuring characteristics and the simplicity of the structure using piezoresistors. But there are some few factors that can deteriorate output characteristics. The most critical are mechanical stresses which contribute to an output signal - applied external medium pressure ratio. The mechanical stresses contribution can result in a shift and ratio zero drift, hysteresis occurrence in an operation cycle, response time change under rapidly changing temperature. Therefore, to design a high-precision PMS it is necessary to match the designed PMS SE components with minimal mechanical stresses on transient interfaces in the SE membranedevice package system, or to make sure of compensating for negative factors influence.

This work is aimed at finding an optimal support chip structure. A comparative analysis has been done to choose among the suggested variants of decoupling a device package, and a structure variant of a support chip that makes it possible to decrease parasitic effect transferred to PMS SE and thus to reduce undesired components in output characteristics has been offered.

\section{THEORETICAL PART}

Undoubtedly, struggling for a maximal result you face with both positive and negative aspects in designing the finished product. If you consider SE accuracy as a priority parameter, then the second most important criterion is simplicity of its manufacturing process. So, both criteria have been used for further consideration and selection of support chips as SE constituent part. The support chip structure should provide a minimal undesirable components contribution to an output signal and the support chip itself can be fabricated in a unique cycle based on microelectronic devices processing line.

Among relatively inexpensive PMS SEs, the most popular has appeared to be mechanical decoupling with a package formed as a massive support chip whose height is several fold greater than a SE chip thickness (model I illustrated in Fig. 1a) [3] or similar support chip but already mounted on a ceramic pipe (model II shown in Fig. 1b). SE membrane installed in this way to a first approximation enables partial removal of mechanical stresses related to SE packaging.

A SE membrane is assembled on a support chip (model I and II) by gluing, soldering and doping [1]. Along with other techniques, a support chip of model I is more often manufactured by electro-stimulated (anodal) bonding of several silicon wafers or borosilicate glass which is joined with SE chip [4]. However, from the technological viewpoint a mechanical decoupling of such a type is not always effective and 


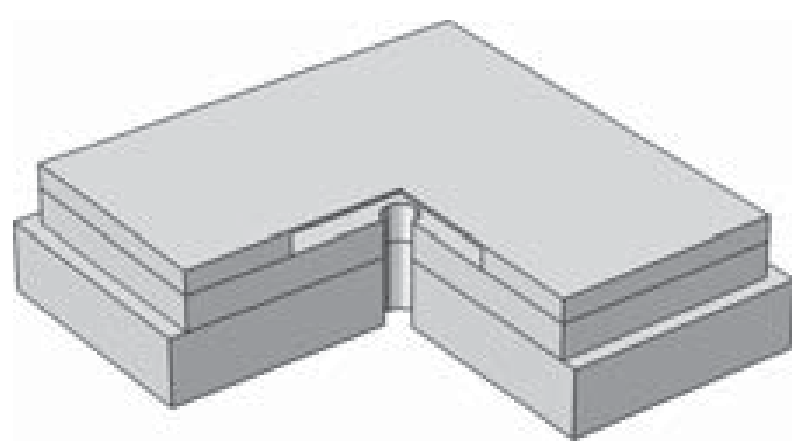

$a \mid a$

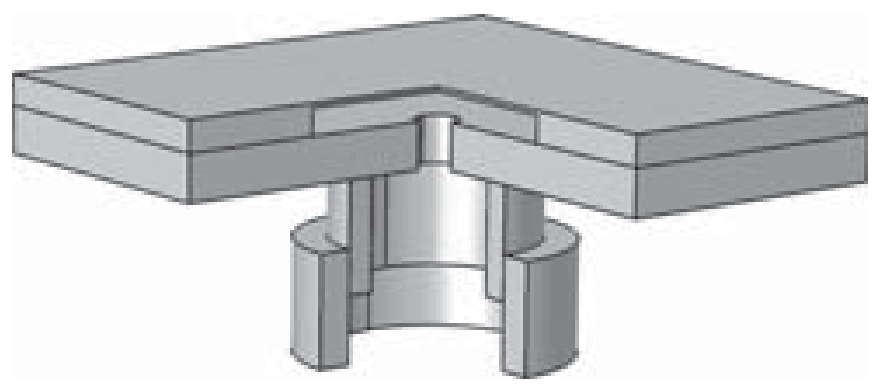

$\sigma \mid b$

Рис. 1. ЧЭ МДД: а) расположение мембраны ЧЭ на массивном опорном кристалле (модель I); б) расположение опорного кристалла на керамической трубке (модель II)

Fig. 1. PMS SE: a) SE membrane located on a massive support chip (model I); b) support chip installed on a ceramic pipe (model II)

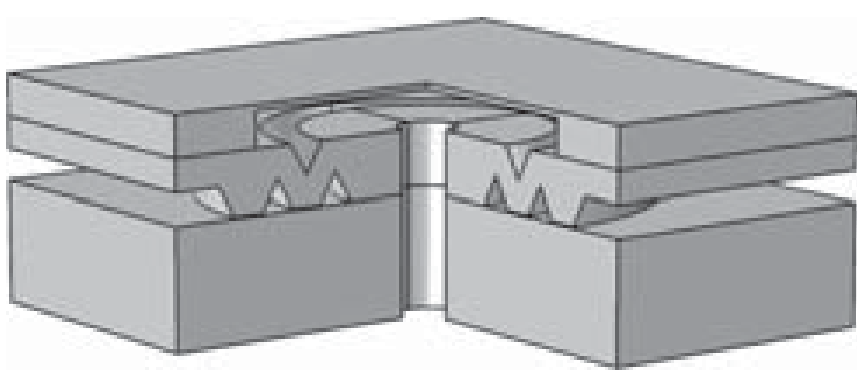

$a \mid a$

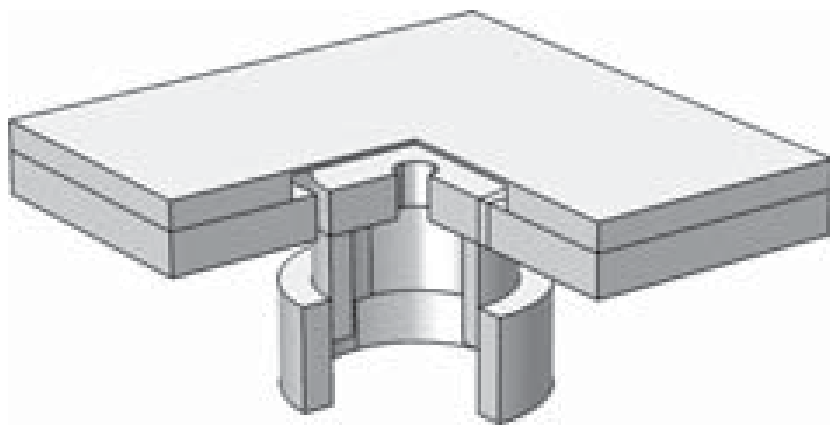

$\sigma \mid b$

Рис. 2. ЧЭ МДД: а) опорный кристалл ЧЭ имеет форму гофрированной поверхности (модель III); б) закрепление опорного кристалла и мембраны ЧЭ осуществляется через подвес (модель IV)

Fig. 2. PMS SE: a) SE support chip has a form of corrugated surface (model III); b) support chip and SE membrane are suspension fixed (model IV)

предусмотренных планарных и объемных термокомпенсационных элементов [5, 6]. Среди имеющихся разновидностей конструкций опорных кристаллов были представлены те, с помощью которых возможно минимизировать механические напряжения, и конструкция которых не привносит дополнительный отрицательный функционал, например, появление зависимости ЧЭ от действующего на него ускорения. На рис. $2(a, \sigma)$ представлены два типа опорных кристаллов (модель III и IV), имеющие в своей геометрии термокомпенсаторы упругих напряжений, а на рис. 3 модель V, предложенная в рамках исследований данной работы.

Поддерживающие кристаллы, в конструкцию которых входят термокомпенсаторы упругих напряжений, формально можно разделить на два класса. В первый класс входят кристаллы, способные компенсировать механические напряжения, действующие вдоль плоскости XY (рис. 26 и рис. 3) (декартовой системы координат), во втором находятся те, которые также минимизируют напряжения в плоскости XY с возможным задействованием направления вдоль оси Z (рис. $2 a$ ).

\section{ЭКСПЕРИМЕНТААЫНАЯ ЧАСТЬ. \\ РАСЧЕТ МЕХАНИЧЕСКИХ НАПРЯЖЕНИЙ В ОПОРНОМ КРИСТАЛАЕ}

При проведении расчетов механических напряжений в рассмотренных вариантах конструкций габаритные размеры и материалы, из которых они изготовлены, были взяты из описания действующих ЧЭ МДД [3]. Чтобы учесть ряд тонких моментов математической модели, в итоговую конструкцию вошли следующие рабочие слои: кристалл с мембраной МДД, опорный кристалл,

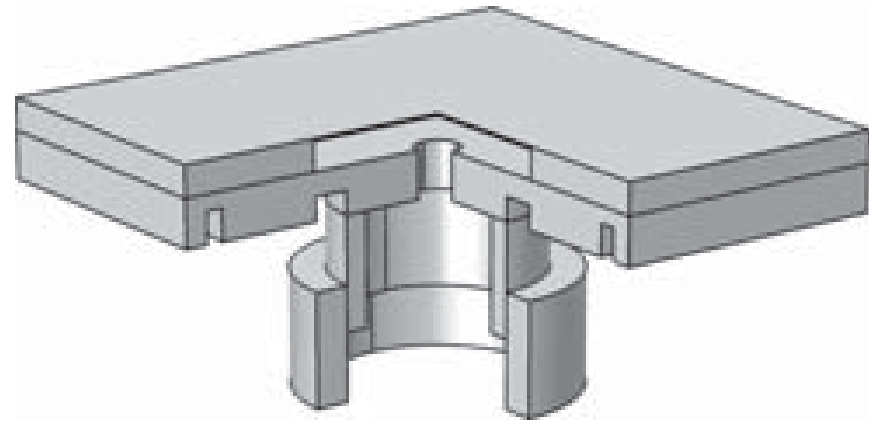

Рис. 3. Опорный кристалл ЧЭ имеет планарные термокомпенсаторы, закрепление осуществляется через керамическую трубку (модель $V)$

Fig. 3. SE support chip has planar temperature compensators that are mounted by a ceramic pipe (model V)

основание корпуса или керамическая трубка, которая является частью корпуса ЧЭ. Считалось, что ЧЭ изготовлен из монокристаллического кремния, как и опорный кристалл с термокомпенсаторами, для моделей II-V. Для модели I кристалл с мембраной располагался на боросиликатном стекле. Основание корпуса у модели I и III выполнено из ковара. У модели II, IV и V закрепление в корпусе осуществляется через керамическую и медную трубочки, последняя вваривается в корпус.

Для выбора оптимальной конструкции среди образцов из разных классов расчет проводился для нескольких схожих моделей. 


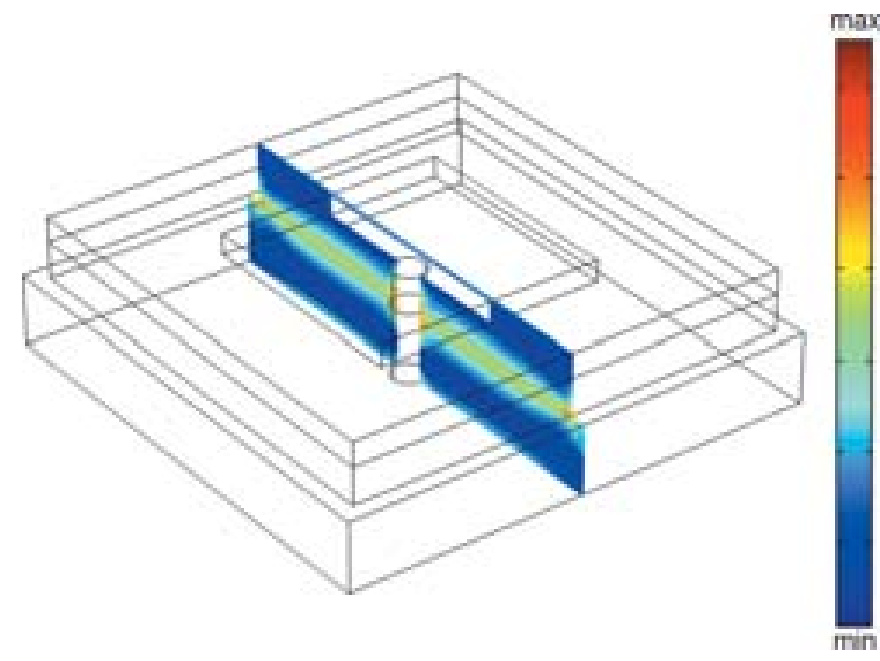

$a \mid a$

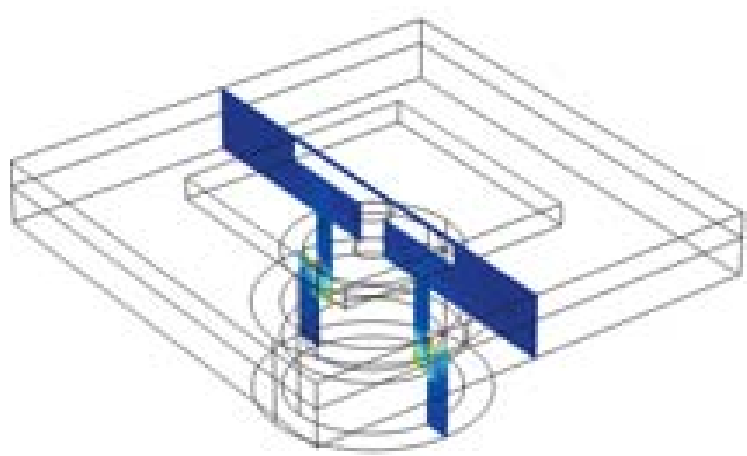

$\sigma \mid b$

Рис. 4. Распределение механических напряжений в ЧЭ МДД для модели I (а) и II (б)

Fig. 4. Mechanical stresses distribution in PMS SE for models I and II

Ниже приведены результаты моделирования методом конечных элементов для опорных кристаллов, обладающих наиболее оптимальными функциональными возможностями среди представителей из каждого класса.

Как показано на рис. $4 a$, если ЧЭ расположен на опорном кристалле из боросиликатного стекла, при изменении температуры (осуществляется разогрев основания, на котором располагается опорный кристалл) наблюдаются механические деформации мембраны, в результате которых мембрана испытывает отрицательный прогиб, направленный против действия потока газа. Подобное поведение мембраны наблюдается и у модели II, когда массивное основание из кремния располагается на керамической трубочке в отсутствие термокомпенсаторов. Итогом такого совместного воздействия со стороны механических напряжений, имеющих противоположные направления, станет падение уровня выходного сигнала, и у внешнего наблюдателя может возникнуть неверное предположение, что измеряемое давление потока газа снизилось. Ситуация повторяется и в области отрицательной температуры, но прогиб мембраны и действие механических напряжений в этом случае уже совпадают по направлению.

В отличие от опорного кристалла, выполненного из стекла, где площадь соприкосновения кристалла мембраны максимальна, у модели III область контакта занимает не более $30 \%$ от нижней грани основания, а у модели II, IV и V первоначальное взаимодействие осуществляется через керамическую трубочку, которая далее закрепляется в медной трубке, жестко сваренной justified due to an increased amount of operations and applied engineering in comparison to a silicon wafer standard processing cycle. Besides, a significant disadvantage of this concept is a requirement that all layers that are constituent parts of a SE and support chip match the material thermal expansion coefficient (TEC). In addition, anodal bonding of two chips leads to pre-stressed state in a SE membrane that has negative effect on piezoresistors characteristics and causes initial bridge unbalance in an electric circuit to which SE is hooked up. The abovementioned case will be illustrated below by PMS SE output signal dependence on applied external pressure (Fig. 8).

An alternative approach to designing a support chip form is based on using predefined planar and bulky temperature compensation elements [5, 6] in its structure. Among already existing support chip structure variations, there have been presented those capable of minimizing mechanical stresses and whose structure does not introduce an additional negative functional, such as the appearance of SE dependence on acceleration. Fig. $2 a, b$ shows two types of support chips (model III and IV) whose geometry has temperature compensators of elastic stresses, and Fig. 3 illustrates model $\mathrm{V}$ offered by the authors in this research

Support chips whose structure consists of temperature compensators of elastic stresses can be formally divided into two classes. The first class covers chips capable of compensating for mechanical stresses affecting along $\mathrm{XY}$ plane (Fig. $2 b$ and Fig. 3) (rectangular coordinate system). The second class includes chips that also minimize stresses along XY plane and may cover direction along $\mathrm{Z}$ axis as well (Fig. $2 a$ ).

\section{EXPERIMENTAL PART. \\ ANALYZING MECHANICAL STRESSES IN SUPPORT CHIP}

While analyzing mechanical stresses in the highlighted various structures, dimensions and materials they are made of have been borrowed from the descriptions of operating PMS SEs [3]. To take into account some critical moments of a mathematical model, the final structure consisted of the following operating layers: a chip with PMS membrane, support chip, a package base or ceramic pipe which functions as a SE component. A SE was considered to be manufactured from single-crystalline silicon as well as a support chip with temperature compensators for models II-V. For model I a chip with membrane was placed on borosilicate glass. Model I and III package base was made of kovar. As for models II, IV and V, their package fixing is done by a ceramic pipe and copper tube, the latter being package-welded.

To choose an optimal structure among various class samples, an analysis has been made for a few similar models. Below are the results of simulation by a finite element method for support chips characterized by the most optimal functionality among each class representatives.

As seen in Fig. $4 a$, if a SE is installed on a support chip made from borosilicate glass under temperature alteration (the base with a support chip is heated up), a membrane 


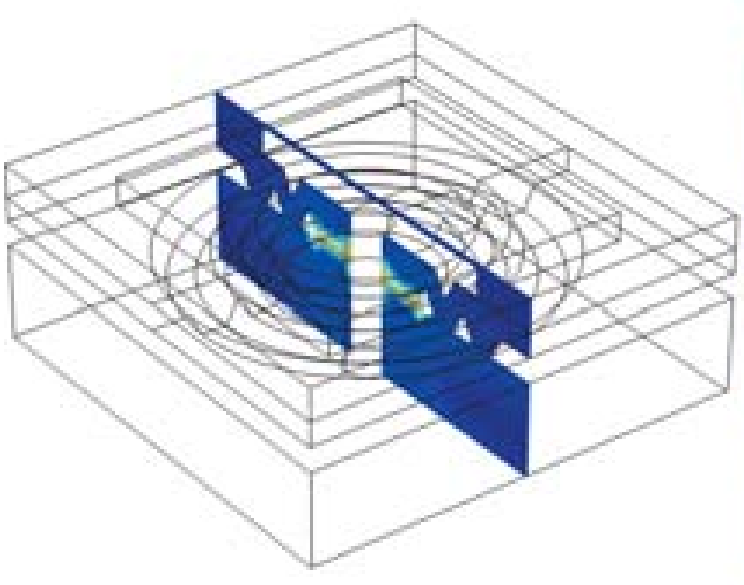

$a \mid a$
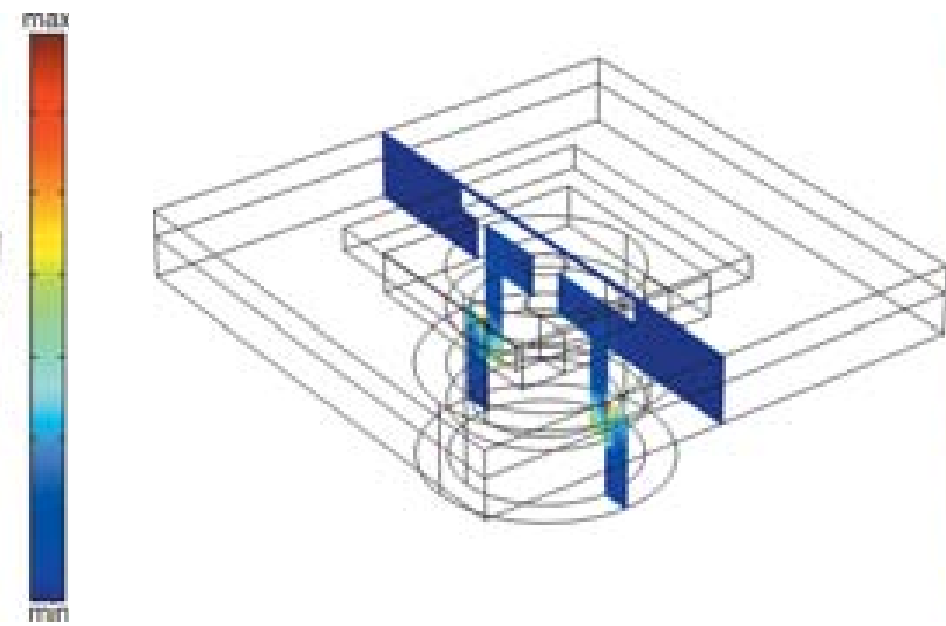

$\sigma \mid b$

Puc. 5. Распределение механических напряжений в ЧЭ МДД для модели III (a) и модели IV (б)

Fig. 5. Mechanical stress distribution in PMS SE for models III (a) and IV (b)

с корпусом. При этом область контакта с керамической трубочкой для моделей II, IV и V также не превышает $30 \%$ от площади. Таким образом, уменьшение области контакта опорного кристалла с корпусом, как продемонстрировано на рис. 5 и 6, способствует снижению области распространения деформаций, что справедливо и для модели II. Однако температурное расширение керамической трубки в случае модели II, на которой располагается опорный кристалл, в силу симметрии задачи приведет к начальной деформации мембраны ЧЭ, что, в свою очередь, также повлияет на выходные характеристики ЧЭ.

Опорный кристалл в форме гофрированной поверхности (модель III) обладает радиальной симметрией, и с увеличением расстояния относительно центра кристалла механические напряжения практически полностью релаксируют. Преимущество подобной конструкции заключаются в том, что среди исследованных аналогов данный тип опорного кристалла наименее подвержен действию механических напряжений, связанных с температурными перепадами, ввиду того, что вся гофрированная поверхность выступает в роли объемного термокомпенсатора. Согласно [7] вариация латеральных параметров опорного кристалла и толщины
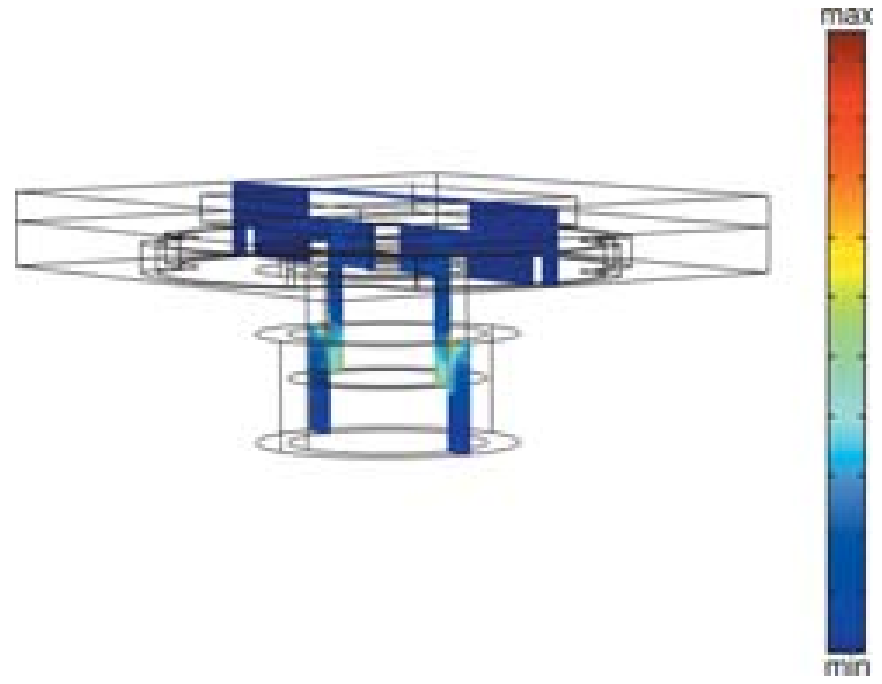

Рис. 6. Распределение механических напряжений в ЧЭ МДД для модели $V$

Fig. 6. Mechanical stress distribution in PMS SE for model V appears to be mechanically strained resulting in a negatively bended membrane in the gas flow reverse direction. A membrane of model II behaves similarly when a massive silicone base is located on a ceramic pipe with no temperature compensators. This joint effect from mechanical stresses of opposite directions will result in output signal decaying, and an external observer might make an improper assumption that the measuring gas flow pressure has been reduced. The analogous situation occurs in relation to negative temperature area but a membrane bend and mechanical stress effect are directed the same way in this case.

In comparison to a glass-made support chip with the maximum membrane chip contact area, model III has contact area of no more than $30 \%$ of the lower base facet but models
II, IV and V interact primarily by a ceramic pipe which afterwards is mounted inside a copper tube rigidly welded to the package. In this case the contact area with the ceramic pipe for models II, IV and V does not exceed $30 \%$ either. Therefore, reducing the support chip contact area with the package as it has been demonstrated in Figs. 5 and 6 makes it possible to decrease strain distribution zones, which is also true for model II. However, as for model II, thermal expansion of a ceramic pipe with a support chip is mounted on due to symmetry will cause initial strain of a SE membrane affecting SE output characteristics.

A support chip in the form of a corrugated surface (model III) possesses radial symmetry, and as distance relative to a chip center increases, mechanical stresses totally relax.
The advantage of this structure is that among the investigated analogs this type of a support chip is the least exposed to mechanical stresses related to temperature variations because the entire corrugated surface functions as a bulky temperature compensator. According to [7] a variation of support chip lateral parameters and corrugated surface wall thickness makes it possible to diminish material stress states up to $95 \%$. Moreover, model III and V structure does not require auxiliary sealing, and such a SE version fits both an absolute sensor and differential pressure. The disadvantage of corrugated support chips is a fabrication complexity to obtain specified (target) crystallographic surfaces by liquid etching from both chip sides and their brittleness (fragility) while being assembled [3] and in highly defective areas. 
стенки гофрированной поверхности позволяет снизить напряженные состояния в материале до $95 \%$. Помимо этого в конструкции модели III и V не требуется дополнительной герметизации, и такой вариант ЧЭ подходит как для датчика абсолютного, так и дифференциального давления. Недостатком опорных кристаллов с гофрированной формой является сложность их изготовления в части получения заданных кристаллографических плоскостей с помощью жидкостного травления с обеих сторон кристалла, их хрупкость при монтаже [3] и в областях высокой дефектности.

В сравнении с конструкцией модели III, в опорном кристалле модели IV, где связь с корпусом осуществляется через закрепленный подвес и трубочку, деформации, вызванные аналогичными температурными колебаниями, также минимальны и не влияют на работу ЧЭ. Все температурные изменения, связанные с внешней средой, на первом этапе поглощаются керамической трубкой, а уже затем подвесом, на конце которого имеется основание для закрепления на трубке. Достоинство такой конструкции заключено в простоте изготовления опорного кристалла, главным элементом которого является основание крепления керамической трубки и плоский подвес, объединяющий основание с остальной частью кристалла. Радиальная симметрия основания и область, где оно располагается, позволяют выполнить механическую развязку с корпусом с минимальным взаимодействием через подвес. Сложности, обременяющие данный вид опорного кристалла и сам ЧЭ, связаны с тем, что для ЧЭ датчика абсолютного давления при такой конструкции необходимо будет изготовить дополнительную защитную крышку для герметизации мембраны ЧЭ. К тому же система, обладающая подвесом, даже с большой степенью жесткости, как в данном варианте, может выступать в качестве концентратора механических колебаний, что является отрицательным свойством конструкции.

Предложенная модель $\mathrm{V}$ опорного кристалла, исходя из его геометрических свойств, достаточно проста в изготовлении, ввиду того что модификация рельефа поверхности пластины потребуется только с одной стороны. С точки зрения кремниевой технологии и его производства, подобное техническое решение имеет ряд преимуществ, поскольку минимизируются возможные технологические уходы и неточности. Геометрический вид термокомпенсаторов у кристалла представляет собой набор из концентрических колец сложной формы, конструкция не является сквозной, поэтому, как было указано выше, для данной модели не потребуется дополнительная герметизация.

\section{ПОАУЧЕНИЕ ВЫХОАНОЙ ХАРАКТЕРИСТИКИ ЧЭ МАА В УСАОВИЯХ ТЕМПЕРАТУРНОГО КОАЕБАНИЯ СРЕАЫ}

Для определения вклада от механических напряжений, которые могут передаваться на мембрану ЧЭ, и получения его выходной характеристики при температурных изменениях среды были выполнены следующие этапы по расчетам:

С помощью среды Comsol Multiphysics выполнена модель мембраны ЧЭ толщиной 20 мкм (рис. 7a).

Используя расчет областей наибольших деформаций мембраны, исходя из полученных данных, были выбраны области расположения тензорезисторов (рис. 7б).

Далее тензорезисторы ЧЭ были включены в мостовую схему, благодаря чему была получена выходная характеристика - зависимость выходного сигнала $\mathrm{U}_{\text {out }}$ от приложенного давления на мембрану.

Получив выходную характеристику ЧЭ для случая, когда мембрана не испытывает механические напряжения, нами были учтены условия температурного разогрева-охлаждения, в результате чего построены характеристики, показанные на рис. 8 .

Согласно приведенным графикам (рис. 8) зависимость выходного сигнала для разных опорных кристаллов испытывает линейное смещение вдоль оси $\mathrm{U}_{\text {out }}$, что связано с механическими напряжениями, вызванными температурными изменениями среды. Для моделей I и II в области положительной температуры наблюдается смещение вниз (рис. $8 a$ ), что, как отмечалось ранее, является следствием противодействия двух типов механических напряжений. При отрицательной температуре уровень сигнала возрастает, что объясняется совпадением направлений действия внутренних и внешних напряжений (рис. 8б). В случае модели III зависимость не изменяется на всем температурном диапазоне, что еще раз доказывает высокую эффективность опорных кристаллов ЧЭ, имеющих форму гофрированной поверхности. Характеристики моделей IV и V опорного кристалла испытывают незначительное смещение, что также подтверждает их эффективность в минимизации упругих полей при развязке ЧЭ с корпусом изделия.
Compared to model III structure, in model IV support chip where package bonding is done by a suspension and tube, strains caused by similar temperature fluctuations are also minimal and do not affect a SE performance. All temperature changes related to external medium are neutralized by a ceramic pipe at the first stage and afterwards by a suspension at the end of which there is a base to fix a tube. The advantage of this structure is simplicity in manufacturing a support chip whose key element is a base to bond a ceramic pipe and flat suspension joining the base with the rest part of the chip. Radial symmetry of the base and its location site enable mechanical package decoupling with minimal suspension interaction. A burden for this type of a support chip and $\mathrm{SE}$ itself relates to a necessity to fabricate for absolute pressure sensor SE an additional protection cover for SE membrane sealing. Moreover, the system even with a highly rigid suspension, as in this variant, can function as a mechanical fluctuation concentrator that is a structure disadvantage.

By its geometrical properties the suggested support chip of model $\mathrm{V}$ is sufficiently simple in production due to a necessity of merely single-side modification for a wafer surface curvature. From the viewpoint of silicon technology and production, a similar solution has a number of advantages as likelihood technology errors and inaccuracies are minimized. A chip temperature compensator geometry looks like a set of complicated concentric rings whose structure is not through. Therefore, as mentioned above, this model will not need additional sealing.

\section{OBTAINING PMS SE OUTPUT CHARACTERISTICS IN TEMPERA- TURE VARIATION MEDIUM}

To define contribution of mechanical stresses that can be transferred to a SE membrane and to obtain its output characteristics in temperature variations medium the following analysis stages have been realized:

Using CAD Comsol Multiphysics 20 micronthick SE has been modeled (Fig. 7a).

Basing on the analysis of the most strained membrane areas and the obtained results, the sites for allocating piezoresistors have been chosen (Fig. 7b).

Afterwards SE piezoresistors have been hooked up to a bridge circuit resulting in output characteristics - ratio of $U_{\text {out }}$ output signal to membrane-applied pressure. 


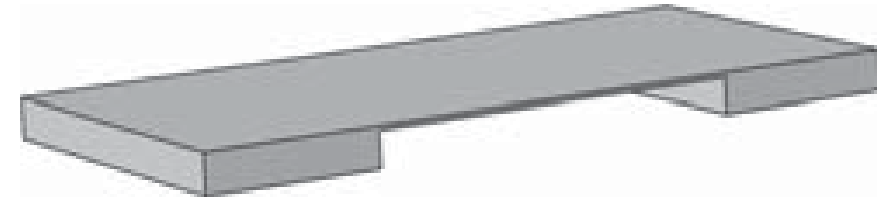

$a \mid a$

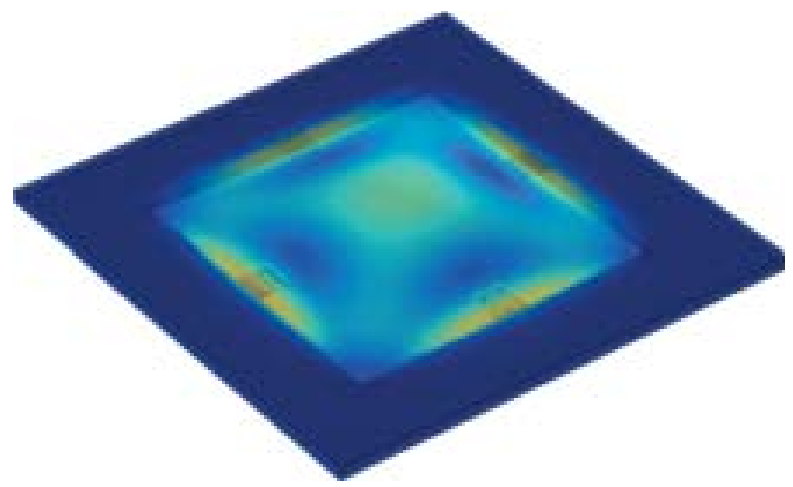

$\sigma \mid b$

Рис. 7. Мембрана ЧЭ МДД: а) модель рассматриваемой мембраны ЧЭ; б) распределение механических деформаций и расположение тензорезисторов (тип меандр) в мембране

Fig. 7. PMS SE membrane: a) model of investigated SE membrane; b) distribution of mechanical strain and membrane piezoresistors allocation (meander type)

\section{ВЫВОАЫ}

В ходе работы было проведено исследование пяти типов опорных кристаллов. Анализ с помощью метода конечных элементов при температурном расширении-сжатии основания корпуса прибора показал, что для моделей I и II опорного кристалла необходимо строгое согласование ТКР материалов между всеми слоями, входящими в систему мембрана-опорный кристалл-корпус, при этом выходной сигнал ЧЭ МДД для модели I в значительной степени зависит от температуры даже при небольших ее изменениях

Среди всех предложенных моделей опорных кристаллов модель III показала наилучшие выходные характеристики, полученные от ЧЭ МДД, в которой наблюдается наименьшее механическое напряжение, передаваемое от основания корпуса к мембране ЧЭ. Минимальное значение передаваемых механических напряжений достигается через утонение стенки гофрированной поверхности опорного кристалла, что подробно рассмотрено в [6]. При этом особенности развитого рельефа опорного кристалла и используемый материал накладывают ряд технологических трудностей на его изготовление.
Проанализировав результаты расчетов и простоту конструкции моделей IV и V с точки зрения технологии производства, мы сделали вывод в пользу развития данного класса опорных кристаллов, имеющих в своей конструкции планарные термокомпенсационные элементы, поскольку данный вариант модели наименее емкий в производстве и наделен наилучшими прочностными характеристиками. Зависимости выходного сигнала $U_{\text {out }}$ от приложенного давления ЧЭ на базе этих моделей находятся в слабой зависимости от температуры окружающей среды, что удовлетворяет выдвинутому требованию о минимизации нежелательных вкладов в выходную характеристику. Предложенная авторами модель V опорного кристалла применима как для ЧЭ датчика абсолютного, так и дифференциального давления, что делает ее наиболее удачным решением среди рассмотренных опорных кристаллов.

\section{НОВИЗНА РЕЗУАЬТАТОВ}

Авторы считают, что в данной работе новыми являются следующие положения и результаты.

1. Предлагается оригинальный вариант конструкции опорного кристалла с планарными термокомпенсационными
Having obtained SE output characteristics when a membrane is not exposed to mechanical stresses, we have taken into account temperature warm-up-cooling resulting in characteristics plotted in Fig. 8.

According to the given plots (Fig. 8) the dependence of output signal for various support chips suffers from a linear shift along $U_{\text {out }}$ axis, which relates to mechanical stresses caused by the medium temperature variations. As mentioned before, in models I and II in positive temperature area a lowering is observed (Fig. 8a) as a result of two counteracting mechanical stress types. Under negative temperatures signal level is going up, which speaks for coincided directions of internal and external stresses (Fig. 8b). As for model III, the ratio does not vary within entire temperature range, which proves high efficiency of SE support chips with corrugated surface.
Support chip characteristics of models IV and $\mathrm{V}$ suffer inconsiderable shift, which also proves their efficiency in minimizing elastic fields while decoupling SE from a device package.

\section{CONCLUSIONS}

In the course of the work five types of support chips have been tested. The analysis made by a finite elements method under thermal expansion-compression of a device package body has demonstrated that a support chip of models I and II requires strict TEC materials matching between all layers being constituent parts of the membrane-support chip-package system. In this case PMS SE output signal of model I depends heavily on temperature, even if variation is the slightest.

Among the offered number of support chip models, model III has shown the best PMS
SE-obtained output characteristics with the least mechanical stress transferred from a package body to SE membrane. The minimum value of the transferred mechanical stress is achieved by thinning a support chip corrugated surface wall which has been thoroughly described in [6]. Besides, peculiarities of a support chip complicated curvature and material in use impede its production.

Having analyzed the design results and the simplicity of models IV and V structure from the production viewpoint, the preference was given to the development of this type of support chip with planar temperature compensation elements in its structure, as the model is the least labor-intensive and is the best in terms of strength. The ratio of $\mathrm{U}_{\text {out }}$ output signal and applied pressure of SE based on these models is slightly dependent on the medium temperature, which complies with the target requirement 

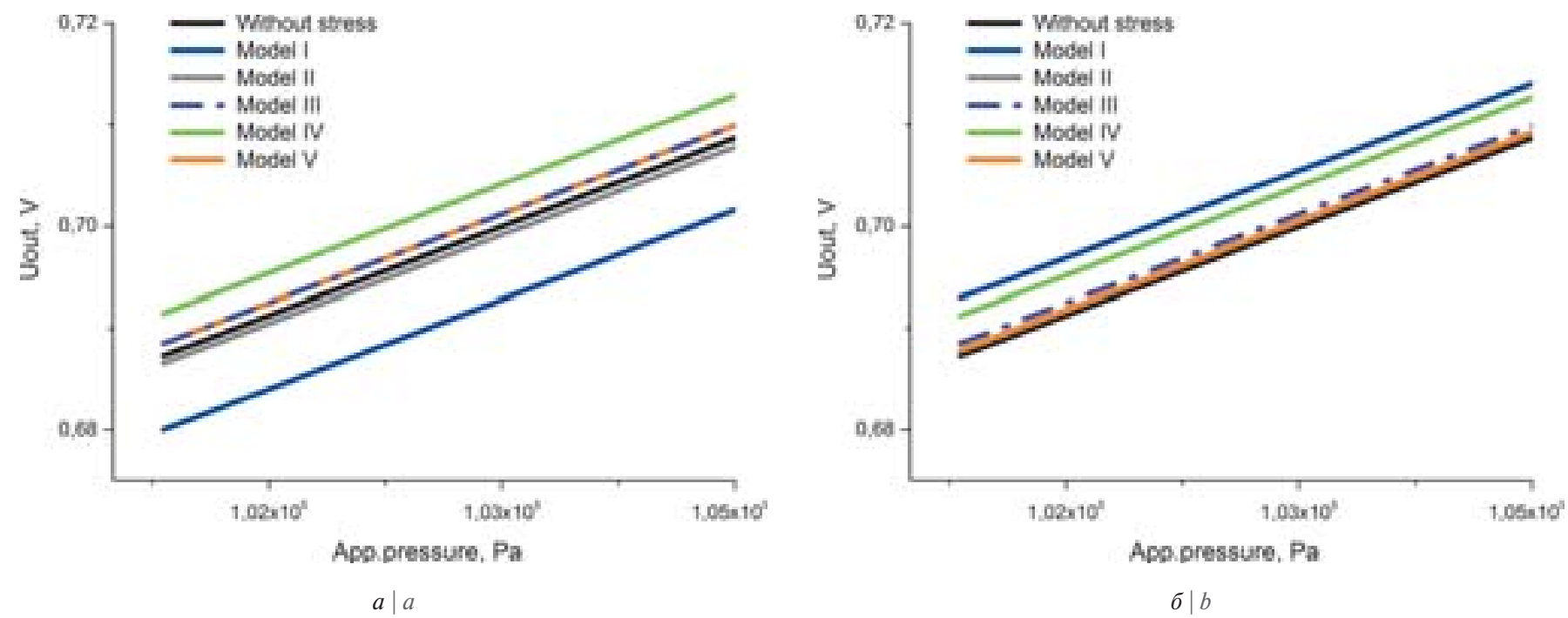

Рис. 8. Зависимость выходного сигнала $U_{\text {оит }}$ от приложенного давления на мембрану в условиях напряженного состояния опорного кристалла: а) система испытывает температурный разогрев; б) система испытывает температурное охлаждение

Fig. 8. Ratio of $U_{\text {out }}$ output signal to membrane-applied pressure under stressed state of a support chip: a) the system suffers from temperature warn-up; b) the system is exposed to temperature cooling

элементами, позволяющий сократить передачу паразитных воздействий на ЧЭ МДД и, тем самым, уменьшить нежелательные составляющие в выходной характеристике $U_{\text {out }}$ от приложенного давления.

2. Конструкция опорного кристалла модели V наименее затратна технологически по сравнению с конструкциями опорных кристаллов со схожими характеристиками.

3. Предложенная модель конструкции опорного кристалла универсальна и применима для микродатчиков абсолютного и дифференциального давления.

\section{АИТЕРАТУРА}

1. Offereins H. L., Sandmier H. Novel Stress Free Assembly Technique for Micromechanical Devices // Proceedings of the Micro System Technologies 90. 1990, pp. 515-520.
2. Hsieh C.-C., Hung C.-C., Li Y.-H. Investigation of a Pressure Sensor with Temperature Compensation Using Two Concentric Wheatstonebridge Circuits // Modern Mechanical Engineering. 2013. Vol. 3, pp. 104-113.

3. Beeby S., Ensel G., Kraft M., White N. MEMS Mechanical Sensors. Lon.: Artech House MEMS Library, 2004. 281 P.

4. Mirza A., Ayon A. Silicon Wafer Bonding: Key to MEMS High-volume Manufacturing // Sensors. 1998, pp. 24-33.

5. Vaganov V. L. Construction Problems in Sensors // Sensors and Actuators. 1991. Vol. A28, pp. 161-172.

6. On-Chip Decoupling Zone for Package-stress Reduction / V. L. Spiering, et al. // IEEE. 1991, pp. 982-985.

7. Membranes Fabricated with a Deep Single Corrugation for Package Stress Reduction and Residual Stress Relief / V. L. Spiering, et al. // J. Micromech. Microeng. 1993. Vol. 3, pp. 243-246. that undesirable contributions to output characteristics should be minimized. The support chip of model $\mathrm{V}$ proposed by the authors fits both an absolute sensor SE and differential pressure, which makes it a worthier solution in comparison to the highlighted support chips.

\section{NOVELTY OF RESULTS}

The authors consider the following points and results in this paper as novel:

1. An original variant of a support crystal design with planar temperature compensation elements has been proposed. It allows reducing the transmission of parasitic effects to the SE of PMS and, thereby, reducing undesirable components in the output characteristic $U_{\text {out }}$ from the applied pressure.

2. The design of the model V support crystal is less expensive in terms of technology as compared to the designs of support crystals with similar characteristics.

3. The proposed model of the support crystal design is universal and applicable to microsensors of absolute and differential pressure.

\section{REFERENCES}

1. Offereins H. L., Sandmier H. Novel Stress Free Assembly Technique for Micromechanical Devices // Proceedings of the Micro System Technologies 90. 1990. P. 515-520.

2. Hsieh C.-C., Hung C.-C., Li Y.-H. Investigation of a Pressure Sensor with Temperature Compensation Using Two Concentric Wheatstone-bridge Circuits // Modern Mechanical Engineering. 2013. Vol. 3. P. 104-113.
3. Beeby S., Ensel G., Kraft M., White N. MEMS Mechanical Sensors. Lon.: Artech House MEMS Library, 2004. 281 P.

4. Mirza A., Ayon A. Silicon Wafer Bonding: Key to MEMS High-volume Manufacturing // Sensors. 1998. P. 24-33.

5. Vaganov V.L. Construction Problems in Sensors // Sensors and Actuators. 1991. Vol. A28. P. 161-172.

6. Spiering V.L., Bouwstra S., Spiering R.M.E.J. On-Chip Decoupling Zone for Package-stress Reduction // IEEE. 1991. P. 982-985.

7. Spiering V.L., Bouwstra S., Burger J.F., Elwenspoek M.C. Membranes Fabricated with a Deep Single Corrugation for Package Stress Reduction and Residual Stress Relief // J. Micromech. Microeng. 1993. Vol. 3. P. 243-246. 